\title{
Forum
}

\section{Keeping the ancient world relevant for modern students with Suburani ${ }^{1}$}

\author{
Christine Delaney, Hannah Smith, Laila Tims, Tony Smith and Will Griffiths \\ Hands Up Education CIC, UK
}

Key words: Latin pedagogy, diversity, Suburani

Engaging students with the far-distant past can be a challenge. We established Hands Up Education, a non-profit community interest company, in 2017 in recognition of the need for materials that reflect the priorities of today's students and teachers. Writing a new textbook series provided an opportunity to reevaluate the traditional perspective and prioritise what is important for students learning Latin in the 21st century.

When we started writing Suburani, we spent a lot of time thinking about the type of characters we wanted to investigate. Who would most engage the students, and who would bring to life the reality and experiences of living in ancient Rome? We knew that the characters we followed would frame the students' understanding of the Roman world and put in context what they learned in their study of Roman civilisation.

When we consulted students and teachers, we discovered that it was the ordinary people who most interested them, people they could empathise with and relate to. In the past, and still now, many Latin courses have focused on the wealthy elite. This is largely because of the extant evidence, most of which comes from the highest rungs of society. For many students, however, the lives and experiences of these individuals are remote and inaccessible. Students may come away from years of studying Latin with a distorted idea of the reality of Roman life. Where possible we wanted to root our characters in historical evidence, and base them on real archaeological findings - a challenge when you are focusing on the people in society who are hardest to find in the archaeological record and the literature.

We planned for the course to reach all corners of the Empire. In each location students would meet new characters, different customs, and see the full diversity of the Roman world. In the storyline, the characters start in Rome, then separately visit Britannia, southern Gaul, Lusitania, Pompeii, Carthage, various cities in Greece, and Ephesus. We decided that our set of characters should travel widely so that students would be able to encounter different places and peoples, and would understand that the Empire was not a single homogeneous place. We also wanted to include characters from outside the Empire, as well as the perspectives of recently conquered

Author of correspondence: Hannah Smith, E-mail: contact@hands-up-education.org Cite this article: Delaney C, Smith H, Tims L, Smith T, Griffiths W (2021). Keeping the ancient world relevant for modern students with Suburani. The Journal of Classics Teaching 22, 64-67 https://doi.org/10.1017/S2058631021000106 peoples. Such perspectives would feature also in the cultural content, which explores civilisations before the arrival of the Romans, not just as part of the Empire. Although it is perhaps unusual that the cast of Suburani, almost all from humble backgrounds, should travel so widely, in order to diversify the storyline and offer students a broad perspective on the Roman world we made the compromise that our ordinary characters would have extraordinary adventures.

It was important to us that our course should provide a balanced view of male and female stories, giving as much coverage to the lives of women and girls as to the lives of men and boys. Women in ancient Rome had a limited public role and could not hold political office. For this reason, they are mentioned much less frequently than men by Roman historians, who were exclusively male. The women who did leave a mark on history are certainly the exceptions. Those whose names occur in literature, such as speeches, letters, poetry and satire, largely come from the upper classes. Women of lower status remain, on the whole, invisible in the literary records. The epigraphical evidence gives us little more information. Although some ordinary women were immortalised with grave markers, the sparse information the epitaphs offer sheds little light on what the lives of these women would really have been like. Mothers, wives, sisters and daughters - the women are almost always defined by the male who commemorates them. However, by piecing together fragments of information from references to women in a wide variety of sources, such as inscriptions, wall paintings, satire and plays, we can get an idea of some of the typical activities and occupations of an ordinary woman. For example, from Juvenal (5.98) we hear of a woman called Aurelia who is a piscatrix, a fishmonger. This occupation is also documented in a funerary inscription set up to Aurelia Nais, a freedwoman (CIL 6.9801). We can also glean information from a variety of non-elite sources such as graffiti and papyri. It is commonly the case that any additional information mentioned in these sources - beyond a woman's name, age, and how many children she bore - tends to be her occupation. Therefore, this was often the starting point when we were creating our characters. Some traditionally female jobs are recorded frequently, such as hairdresser, wet nurse and midwife. Then, there are some more unexpected trades, such as that of the piscatrix mentioned above. In general, the lack of evidence for women in certain trades does not mean necessarily that it was rare, but only points to the standard practice of not recording female occupations on 
gravestones. The surviving records that have inspired our characters include the grave marker of a popinaria (barkeeper) set up by her husband (CIL 14.3709) and a reference to an unguentaria (perfume seller) by Pliny the Elder (HN 8.14). These brief appearances give us a glimpse of a class of working women, although providing little information about their lives.

Consideration was given to the diversity of age among our cast of characters. Suburani is designed for secondary school students, and lead characters of a similar age are an appealing choice, inviting easy comparisons between our students and their ancient counterparts. Yet it was also important to represent the full breadth of Roman society. The infant mortality rate was tragically high in ancient Rome. Such a death rate would have cast a shadow over the lives of parents and families, and without common means of contraception many women would have spent a large portion of their adult life pregnant. We studied the overarching trends and thought about how they would have affected the experiences of our characters as individuals. Older characters, too, needed to be represented, in order that students might consider the full gamut of human life and experience in the Roman Empire. Without pensions and a welfare system, the practicality of ageing was a far darker prospect than it is for many today. Gabrus and Manius are two elderly characters who are caught in desperate situations, unable to find work. Manius is a beggar whom we meet in Chapter 1 and who dies of a fever on the street in the Subura. The portrayal of his harsh existence acts as a reminder of the continuing struggle in the lives of the poor.

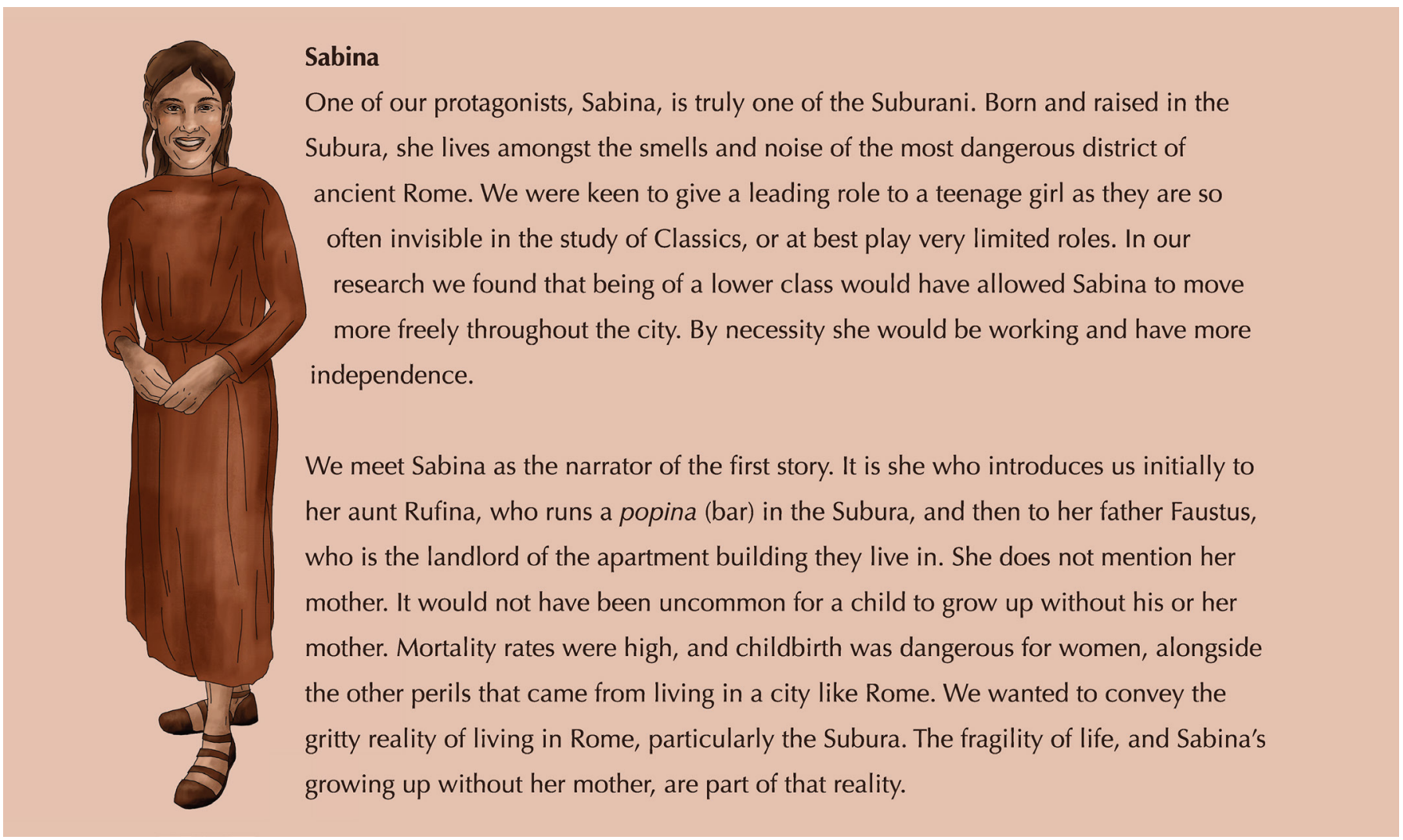

While providing a wide range of characters to whom students can relate, we also wanted to introduce challenging topics. When studying Roman civilisation, it can be a difficult process to reconcile that which we recognise from our own modern experience with the aspects of the ancient world which are totally alien. Faustus' money problems and Sabina's love interests can make them feel familiar, while other aspects of their lives are jarringly different from our own modern experiences. The institution of slavery, which dehumanised men, women and children into commodities, is clearly something we cannot empathise with and it is important to separate our own modern standards of morality from ancient ones. For example, we think of Alexander (a mosaic maker and Sabina's love interest) as a 'good guy', and therefore we were reluctant to portray him beating his slave. However, we felt it was necessary to depict what was likely a routine reality, even though these actions are at odds with his presentation as a positive character with whom students can identify and empathise. Students may be shocked by the actions of some of the characters when read in a modern context, but the representation of those actions is an important part of seeing the reality of life in ancient Rome, and it creates opportunities to discuss the question of relative moralities.

The study of the Latin language and Roman civilisation is not static; as our own sensibilities change, so too does our interpretation of the ancient world. We look at the surviving evidence with different priorities which speak to our modern interests. In writing a new course the opportunity presented itself to take advantage of the advances in archaeology and technology that have recently reset some traditional ideas about the Roman world. For example, isotopic analyses of teeth and bones have brought to light a much more ethnically diverse Roman population than has traditionally been portrayed, in both the city of Rome and the Empire. As far north as Londinium, archaeologists have found skeletons with sub-Saharan ancestry, and by investigating the mitochondrial DNA they are able to discern features as specific as hair and eye colour. ${ }^{2}$ When we started writing Suburani four years ago, we felt strongly that teachers and students needed new materials in line with their own sentiments. Since then, the growing momentum of movements such as 


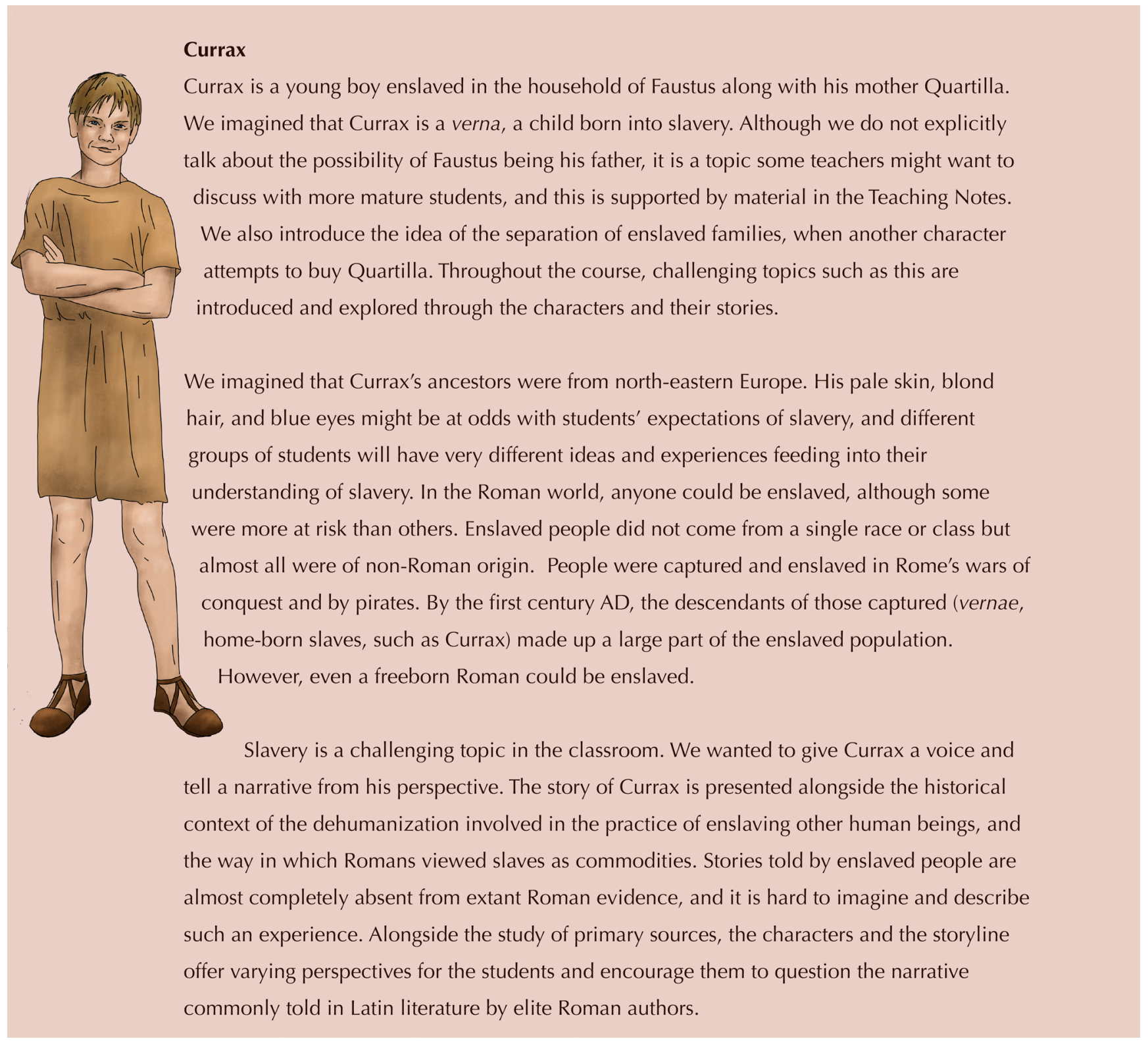

Black Lives Matter and \#Metoo have cemented the need for new materials for teachers of Latin to better represent diversity.

In line with providing materials which spark the interest of modern students, we have also created digitally-enhanced resources and teacher tools. The online edition of Suburani includes all the content of the print edition and its responsive design adapts to the size of the user's screen, enabling students to study from home or school using smartphones, iPads and tablets, desktops and laptops.

Our software is able to mark translations automatically and provide immediate feedback. These marked activities are also visible to teachers, who are thus able to set homework and review the student's marked responses before preparing the next lesson. This approach enables teachers to focus on preparation rather than marking, and plan lessons based on the student's performance. The software also records student progress in interactive resources and creates an automated online mark-book for the teacher.

All vocabulary used in Suburani is carefully chosen and tracked throughout the course. As a result, words from the Eduqas and
OCR defined vocabulary lists for GCSE are regularly repeated and account for two out of three words in the stories. The Suburani vocabulary trainer provides each student (and their teacher) with both an overview and a detailed analysis of their vocabulary acquisition. Using spaced repetition, the software focuses on the vocabulary with which the student needs more practice, shows when they last logged in, how long they have spent on the trainer, their overall score to date and precise word-level progress.

The vocabulary trainer and the online mark-book make it easy for teachers to pinpoint items of vocabulary or areas of language where individual students may need more explanation or practice, and also to see trends across the class as a whole. Differentiated versions of the language exercises can then be downloaded and printed to enable teachers to meet the individual needs of each student.

Suburani has been developed and trialled in collaboration with hundreds of teachers who continue to be part of a growing community, sharing expertise and creating shared resources. Resources created by teachers using Suburani are reviewed and 


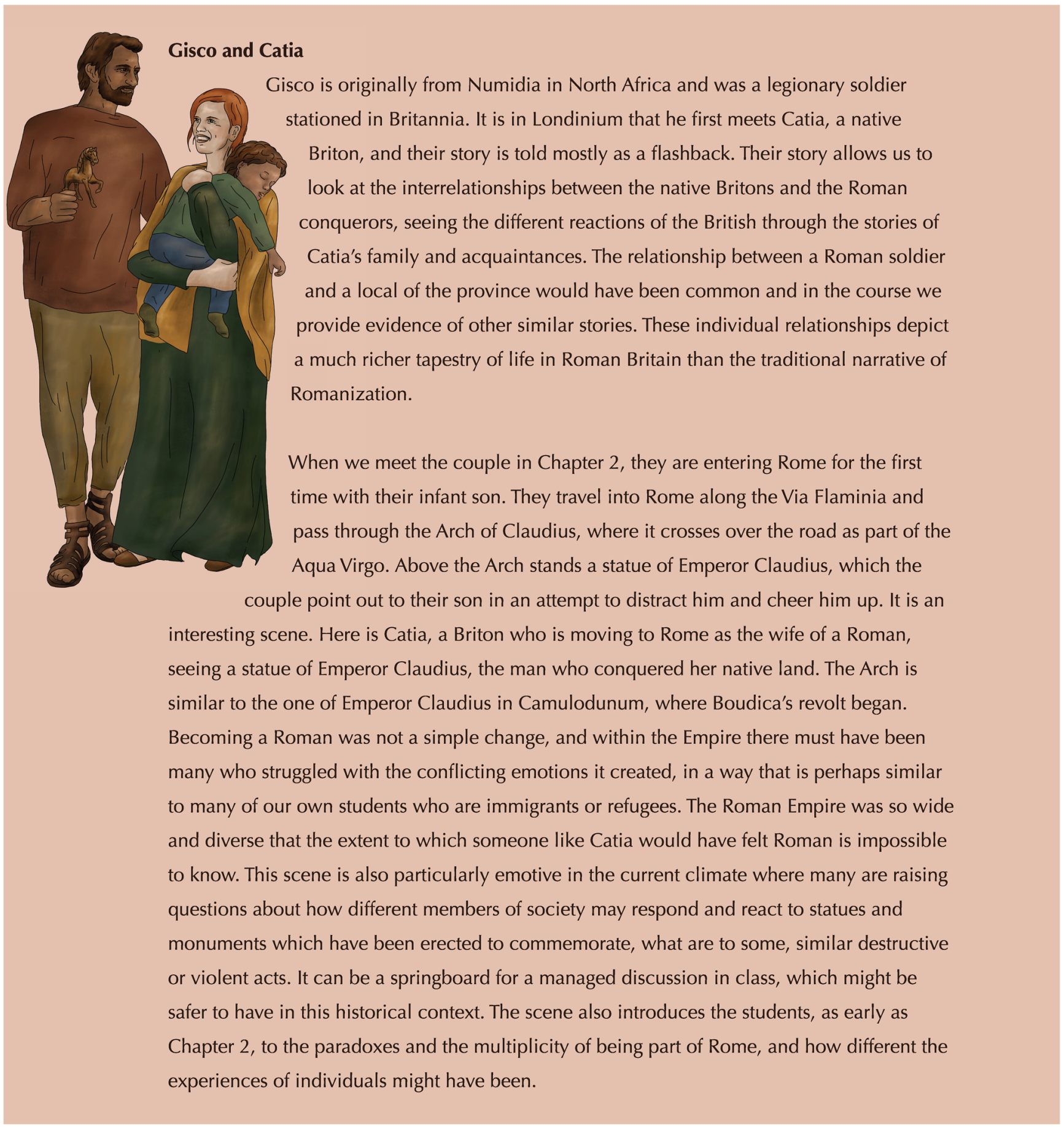

uploaded, curated to individual topics within each chapter. The community model allows teachers to expose their students to a wide variety of teaching styles and provides a large number of ready-to-use resources right at their fingertips. As a Community Interest Company, the proceeds of all Hands Up's materials are used to support and grow Classics teaching in schools. By building a community, we are creating a sustainable future for Classics teaching in schools.

There is much to excite and engage modern students in the study of the ancient world, both what is recognisable and familiar and what is alien and uncomfortable. The creation of Suburani is the next step in the long history of the study of Classics, moving with the times and aligning with modern priorities.
You can order a free inspection copy of Suburani Book 1 for your school now. One inspection copy is available per school.

You can also find out more and try out the first two chapters of Suburani for free at suburani.com.

\section{Notes}

1 An earlier version of this article appeared in The Classical Outlook 95.3, and was first presented at the virtual 2020 ACL Institute as the session, 'Character-based learning in Suburani: why the who matters.'

2 The surprising diversity of Roman London, https:// www.museumoflondon. org.uk/discover/surprising- diversity-roman-london-docklands. This article from the Museum of London gives an overview of new research about Roman London. 